\title{
Study on Construction of Practical Teaching System for Logistics Transportation Major in Higher Vocational Colleges
}

\author{
Shujing Liu ${ }^{1}$, Chungang Niu ${ }^{1}$ \\ ${ }^{1}$ Hebei Jiaotong Vocational and Technical College, Shijiazhuang, 050035, China
}

Keywords: higher vocaiotnal college; logistics transportation major; practical teaching system

\begin{abstract}
With development of economic globalization since 1990s, modern logistics industry rapidly rises globally. Rapid development of logistics industry leads to large-scale demand for logistics personnel. Many higher vocational colleges set up logistics transportation major. It's worth noting that the courses of logistics transportation major are closely related to practice. To cultivate excellent professional personnel for logistics transportation, construction of practical teaching system for this major should be valued highly. This paper discusses the importance of practical teaching in vocational education, analyzes problems existing in construction of practical teaching system for logistics transportation major in higher vocational colleges and proposes countermeasures to overall construct practical teaching system for logistics transportation major in higher vocational colleges.
\end{abstract}

\section{Introduction}

Practical teaching system is a significant constituent part of cultivation of personnel with practice and innovation abilities by higher vocational colleges. To improve practice ability of vocational college students must be highly valued by Chinese higher vocaiotnal colleges. Currently, China's logistics transportation industry develops rapidly. There is a huge gap for technical logistics personnel. The positioning of logistics transportation major of higher vocaiotnal colleges must adapt current era development so as to cultivate technical personnel mastering logistics distribution, transportation and warehouse and owning proficient logistics operation ability. Here, the author mainly states practical teaching system of logistics transportation major in higher vocaiotnal colleges.

\section{Importance of practical teaching in vocaiotnal education}

Practical teaching refers to a teaching mode with the core objective of cultivating learners' comprehensive vocational ability. It mainly aims to arrange learners to observe, operate or practice to help them consolidate and enhance theoretical knowledge related to major cultivation objectives and develop practical skills and social skills required in future work. Generally, practical teaching and theoretical teaching supplement each other. Its functions is mainly to jointly construct learners' comprehensive quality and improve learners' survival skills in society, mainly involving professional skills and code of conduct in life etc. For vocaiotnal college students, practical teaching is not just the process of applying theoretical knowledge in practice, but also a process of further learning. During implementation of practical teaching, vocational college students have opportunities to contact specific problems and tasks and encounter practical knowledge which cannot be learned in books. Especially in enterprise internship process, it is just s process of examining theoretical learning, but also a process of learning practical knowledge.

\section{Problems in construction of practical teaching system for logistics transportation major in higher vocaiotnal colleges}

Firstly, there is lack of systematic practical teaching system. Some colleges are gradually exploring practical teaching for logistics management course, but since practical teaching link has congenital defects, it often becomes formalistic. Some teachers will simply consider practical teaching means to lead students to visit logistics transportation enterprises and know relevant logistics facilities. They fail to deeply know specific operation process. Secondly, teaching materials of logistics transportation major in most vocational colleges have such problems of too strong theoretical property and weak practicalness. These teaching materials are often written by college 
teachers. Very few enterprise workers participate in writing teaching materials. Thus, the contents of teaching materials cannot keep pace with industrial development. Further, teachers divide knowledge in teaching process and it is hard for students to comprehensively sand systematically master theoretical knowledge and skills of logistics transportation major. Thirdly, practical teaching teachers are not arranged rationally. Nowadays, practical activities in higher vocaiotnal colleges are tutored by teachers in the colleges. Practical course outside the campus is mainly carried out in enterprises. So, colleges generally arrange few living teacher to guide their daily life and do not arrange professional teachers in logistics transportation major to guide students to take part in practical work in enterprises. In this way, the allocation of practical teaching teachers is to the disadvantage of practical guidance of students. Thus, it is hard to form practical teaching system. Meanwhile, teachers of some higher vocational colleges lack enough practical skills and cannot give play to guiding function for students in practical reaching.

\section{Countermeasures to comprehensively construct practical teaching system for logistics transportation major in higher vocaiotnal colleges}

\section{(I) To form sound and perfect practical teaching system for logistics transportation major}

To perfect practical teaching system for logistics transportation major, innovation of theoretical knowledge learning and diversified teaching methods, enhancement of campus training and construction of off-campus training base are indispensable.

Firstly, implement diversified teaching methods to create interactive teaching mode. Courses of logistics transportation major have very strong specialty, many professional terms, dull and boring contents and involve large quantities of logistics equipment and tools. Vocational college students need perceptual cognition. So, teachers must apply different teaching methods and means according to contents and features in teaching process to make vocational college students to participate. For example, about logistics equipment and facilities, teachers can apply multimedia equipment to play pictures or videotapes. Through overall explaining distribution process, teachers can be based on role play and scenario simulation to make students act as distribution, order picking, allocation, delivery, purchasing personnel and suppliers to complete the following process: subbranches launch purchase request to the headquarters; the headquarters sends purchase request to suppliers; deliver goods to the distribution center and then deliver them to subbranches from the distribution center. Interactive teaching can make students have opportunities to participate in classroom teaching and grasp knowledge in scenario simulation. Meanwhile, in course teaching arrangement, teachers should overall excavate relevant case resources and collect relevant cases in combination of actual development status of logistics industry to enrich teaching contents. During implementation of case teaching, teachers must guide students to have a thorough grasp of various cases and deeply analyze and understand each case. In this way, students can not just learn professional knowledge, but also analyze relevant problems. Therefore, teachers must let students speak out freely and cultivate their innovation thinking ability,

Secondly, appropriately arrange campus training and cultivate students' practical operation ability. Campus training mainly includes single function practice and comprehensive simulation practice. Single function practice is mainly arranged according to course schedule, while comprehensive simulation practice is completed in comprehensive simulation training room in allusion to relevant major after the course is finished, such as sand table simulation system. The above training activities can apply this system for training to make vocational college students familiar with the whole process of logistics work and improve their professional quality.

Thirdly, enhance construction of off-campus training bases. Higher vocational colleges can jointly set up off-campus training bases with transportation, storage and logistics enterprises and carry out school-enterprise cooperation in many aspects to boost students' practical ability on the basis of learning-working combination. Teachers can lead students to visit logistics enterprises to make them know the operating mechanism and form preliminary cognition of logistics industry. Then, at least four-week on-the-job internship can be arranged to make students carry out practical operation in cooperative enterprises so as to improve their practical skills. 


\section{(II) To reform practical reform of teaching materials of logistics transportation major}

Currently, most vocational colleges have the problems of too strong theoretical property and weak practicalness. Teaching materials of logistics transportation major in higher vocational colleges are mainly written by teachers in higher vocational colleges and lack participation of enterprise employees. Thus, division of teaching contents is caused. Students cultivated by higher vocational colleges do not need to pursue theoretical systematicness and completeness. They just need to master necessary theoretical knowledge of logistics transportation major. They should mainly focus on practicability and pertinence of logistics transportation major. During writing teaching materials of logistics transportation major, it is required to enhance participation force of enterprise experts. Teaching materials should be jointly written by teachers in the major and enterprise experts, keep close contact with enterprise practice, reduce the proportion of basic theoretical knowledge and increase practical application skills. Theoretical teaching materials and practical teaching materials should be prepared according to course design and teaching planning. Based on actively mastering logistics transportation knowledge, it is required to better mobilize students' practicalness.

\section{(III) To perfect practical teaching team of logistics transportation major}

The functions of teachers not just lie in imparting theoretical knowledge, but also lie in discovering students' mastery of knowledge and correcting their mistakes. Practical teaching teachers are scarce to a large extent. This is reflected in two aspects. On the one hand, most teachers in higher vocaiotnal colleges lack practical skills; on the other hand, professional technical personnel in enterprises lack teaching experience. This leads to the situation of seriously insufficient teaching team. Thus, arrangement of practical guidance teachers is caught in a dilemma. For this, trainings with different contents can be carried out for the personnel in two aspects. For professional teachers in higher vocaiotnal colleges, they should be given opportunities to work in the production line in enterprises to enhance various kinds of advanced technical knowledge and be familiar with various operation procedures. Only through deeper practice, teachers can well know logistics industry and prepare teaching materials to guide students' practice. On the other hand, for professional technical personnel with rich practical experience in enterprises, higher vocational colleges can employ them as part-time teachers to guide practical learning of students. For these teachers, it is very necessary to communicate and coordinate with enterprises more fully so as to strive for corresponding training for such personnel and make them undertake the tasks of practical teachers. Besides, corresponding time should be arranged to make off-campus and campus practice teachers to comprehensively communicate so as to make sure vocaiotnal college students have new gains in practice.

(IV) To deepen construction of school-enterprise cooperation mode of logistics transportation major

The development space of school-enterprise cooperation carried out in higher vocational colleges is very wide. This is mainly because the objectives of schools and enterprises are consistent. The process is based on complementing each other's advantages to realize enterprise benefits. Enterprises need to accept those interns with strong practical ability and solid basic knowledge. In the cooperation process, students' practical operation ability can improve so as to realize excellent cooperation between schools and enterprises and radically solve the problem of disconnection between personnel and market demand. Enterprises can provide higher vocational colleges with ideal places, equipment and practical guiding personnel with rich experience for practical teaching, while higher vocaiotnal colleges provide enterprises with students with certain theoretical knowledge and practical ability. The practical teaching effects of logistics transpiration major are not very ideal. This is because the openness and operability of logistics transpiration as a new interdisciplinary subject are very flexible. Nowadays, various teaching links are often closed or semi-closed. Regardless of indoor training room or off-campus training base, most time for practical teaching is in campus. Even in the final semester, practical learning can be conducted in enterprises. However, in reality, what one learns is different from what they do in practical work. Besides, practical guiding teachers of enterprises are insufficient and self-discipline ability of 
vocaiotnal college students is poor. Thus, the expected effects of practical teaching are not ideal.

To practically change this situation, the sole method is to encourage students to go out. Students' study in enterprises can be arranged in multiple different semesters. To be more specific, there are three stages: in the first stage, the primary task is post cognition. This can be implemented in the first semester after new students enter the colleges. In this stage, colleges can arrange students to visit off-campus training bases and invite professional technical personnel of enterprises to organize special lecture to make students closely contact enterprise at the beginning and then improve profound perceptional cognition of sociality and enterprises. In this way, students can approve and know future vocaiotnal selection. Students can be arranged to take part in corresponding activities in enterprises. In the second stage, the main content is on-the-job internship. This can be arranged in winter and summer vacations after students learn foundation knowledge. In this stage, students apply professional ability they master to improve their ability in on-the-job practice and make up for their shortcomings. In this stage, internship enterprise arrange personnel to guide students, explain post duties, job contents and system and carry out field demonstration. Guiding teachers of higher vocaiotnal colleges should actively cooperate with internship enterprises to manage students. The third stage is post practice stage. In this stage, the main task is that students practice in cooperative enterprise with at least a half year to enhance comprehensive skill training before they take up the job officially.

\section{Conclusions}

To sum up, improvement of skill level of vocaiotnal college students cannot be separated from continuously development of practical teaching. Logistics transportation major should be oriented to personnel demand of employment units, take promotion of students; vocaiotnal ability as the center and focus on improving students' professional skills to deeply explore practical teaching laws and reform inherent practical teaching system so as to construct practical course system, implement practical teaching reform and explore practical personnel training ways which not just own distinctive development features of modern logistics industry and meet enterprise requirements.

\section{Acknowledgments}

This thesis is a project of higher educational reform in Hebei province in 2012 (project No.: 2012GJJG187) and the project that was funded intensively in college-level higher educational reform of Hebei Jiaotong Vocational \& technical College (project No.: 2011002). The task name is Research on Higher Vocational Schools' Practical Teaching System Construction of Majors Related to Transportation.

\section{References}

[1] Wang Junfeng, Study on construction of practical teaching system for logistics management major in higher vocational colleges [J]. Vocational \&Technical Education Forum, 2012 (6)

[2] Jin Yan, Study on practical teaching logistics management major in higher vocational colleges based on "integration of teaching, learning and practice" [J]. Journal of Chengdu Aeronautic Vocational \& Technical College, 2013 (4)

[3] Duan Chunhui, Countermeasures and suggestions on improving practical teaching ability of logistics management major in higher vocational colleges [J]. Journal of Jixi University, 2013 (9)

[4] Zhang Zhuoyuan, Exploration of construction of practical teaching system for logistics management major in higher vocational colleges [J]. Education Teaching Forum, 2013 (31)

[5] Wang Haocheng, Research and practice of 6S management mode in practical teaching of logistics management major in higher vocational colleges [J]. Logistics Technology, 2014 (1) 